\title{
Weaving a living: gender, craft, and sustainable resource use in Botswana
}

\author{
Rachel B. DeMotts ${ }^{1}$ \\ University of Puget Sound, USA
}

\begin{abstract}
Botswana baskets are both an emblematic cultural symbol and a popular tourist souvenir, made by women from natural materials and reflecting gendered experiences of work, creativity, and resource use. The expansion of their production for sale over the past 30 years has often led to concerns about strain on the natural resources used for weaving, but more recently, the ways in which women talk about how they access these materials has changed. Rather than framing resources as scarce and under threat from poor harvesting practices, increasing numbers of women describe shifts in use practices that reflect growing awareness of the need to protect and cultivate plants such as hyphaene petersiana, or mokola palm. This change reflects the importance of rethinking what constitutes community-based natural resource management to include not only formalized trusts, but informal networks through which women harvest and use forest resources. It also highlights the insights of political ecology in considering the ways in which power impacts natural resource use, while emphasizing the need to expand notions of knowledge to become more inclusive and grounded.
\end{abstract}

Key Words: Gender, political ecology, community-based conservation, Botswana, craft

\section{Résumé}

Les paniers du Botswana sont à la fois un symbole culturel emblématique, et un souvenir touristique populaire. Elles sont faites par des femmes à partir de matériaux naturels et incarnent le genre par le travail, la créativité et l'utilisation des ressources. L'expansion de leur production sur le marché au cours des 30 dernières années a souvent suscité des inquiétudes quant à la pression sur les ressources naturelles utilisées pour le tissage. Mais plus récemment, les façons dont les femmes parlent de leur accès à ces matériaux ont changé. Ils disaient que les ressources étaient rares et menacées par de mauvaises pratiques de récolte. Aujourd'hui, beaucoup de femmes sont plus conscientes de la nécessité de protéger et de cultiver des plantes telles que hyphaene petersiana, ou mokola. Cela se reflète dans leurs pratiques. Ce changement illustre l'importance de repenser la gestion communautaire des ressources naturelles pour y inclure non seulement les fiducies formalisées, mais aussi les réseaux informels. Grâce à elles, les femmes récoltent et utilisent les ressources forestières. L'article met également en évidence les points de vue de l'écologie politique en examinant les façons dont le pouvoir a un impact sur l'utilisation des ressources naturelles, tout en soulignant la nécessité d'élargir les notions de connaissances pour qu'elles deviennent plus inclusives et ancrées.

Mots clés: Genre, écologie politique, conservation communautaire, Botswana, artisanat

\section{Resumen}

Las canastas de Botswana hechas con materiales naturales, son emblemáticos símbolos culturales y populares recuerdos turísticos fabricados por mujeres, los cuales reflejan experiencias laborales de género, creatividad y uso de recursos. La expansión de la producción y venta por los últimos 30 años ha generado preocupación por el agotamiento de los recursos naturales utilizados para su tejido, pero más recientemente, las formas en que las mujeres hablan sobre cómo el acceso a estos materiales ha cambiado. En lugar de considerar los recursos como escasos o bajo la amenaza de cosechas escasas, un creciente número de mujeres describe cambios en las prácticas de uso que muestran un aumento en la preocupación por la necesidad de proteger y cultivar plantas como la hyphaene petersiana o palma mokola. Este cambio refleja la importancia de reconsiderar cómo es el manejo de recursos naturales basado en la comunidad para incluir no solamente

\footnotetext{
${ }^{1}$ Dr. Rachel B. DeMotts, Associate Professor and Director, Environmental Policy and Decision-Making Program, University of Puget Sound, 1500 N. Warner St. CMB 1052, Tacoma, WA 98416, USA. Email: rdemotts "at" pugetsound.edu.
} 
créditos formales, sino redes informales a través de las cuales las mujeres cosechan y usan los recursos forestales. De igual manera se destacan las percepciones de la ecología política al considerar las formas en que el poder impacta en el uso de recursos naturales, mientras que se enfatiza la necesidad de extender las nociones de un conocimiento que promete ser sólido e inclusivo.

Palabras clave: Género, ecología política, conservación comunitaria, Botswana, artesanía

\section{Introduction}

The use of mokola isn't new. Our grandfathers used to use it. They used to cut leaves with a knife. Now people are using hoes... To get mokola is difficult now. We have to travel to faraway islands to get mokola or buy it. We have nothing to use without using mokola.

-Resident of Etsha 6, quoted in Cunningham and Milton (1982).

There is no change [in local resources available], there is a fair amount of replacement and people harvest sustainably - they do not kill the plants so they can come back and harvest. We sometimes come across elephants and it is far.

-Resident of Etsha 9, 2013

The mokola palm basket (made from Hyphaene petersiana) has become an emblematic souvenir of Botswana, its fine stitching and richly earth-toned geometric patterns representing a safari experience of wild Africa that has the added benefit of packing easily into a suitcase without breaking. Baskets are most commonly made by women; they are a household artefact used for everything from grain storage to brewing beer in communities not just in Botswana, but throughout the region. Weaving is usually a social activity, performed by women sitting together in courtyards while children play and conversation percolates. Even the patterns woven into the threadlike strands of boiled, dyed palm carry cultural stories about wildlife and traditional authorities - for example, passing on wisdom about the peaceful nature of the giraffe in a design called 'The tears of the giraffe.'

Baskets, however, are also vessels for other things. As a commodity, they carry a historically situated notion of 'traditional, rural Botswana' into the broader economy. But as tourism has grown and demand has changed over time, so have their importance and the ways in which they are produced. They now represent access to cash in rural areas, where the women who make them may have few or no other options for earning income. That income is predicated on the use of natural resources - the palm itself and the dye trees that provide color to its pale, thin leaves. And as the market for baskets has expanded, so has pressure increased on the use of these resources. Predictions of palm and dye shortages have been prevalent since the commercialization of the basket industry beginning in the mid-1970s. But does that mean that palm baskets are an unsustainable commodity?

Employing a political ecology lens can help elucidate not only changes in resource use over time, but how women as the primary resource users understand changes in accessibility of natural resources, adaptation of management strategies, and environmental education. This approach foregrounds women's perspectives of how use of, and access to weaving materials has changed over time. Recent studies of women's empowerment, for example, foreground the importance of diversified livelihood options (often tied to natural resources) (Khumalo and Freimund 2014), as well as the importance of recognizing that multiple forms of access to knowledge and resources may be even more important than formal control of them (Goldman and Little 2015). Previous work with women who weave often reflects a dire discourse of change, that predicts basketmaking to be on an unsustainable course. This, however, is not universally true especially when examined through the eyes of women who use and care for these resources. Highlighting local knowledge of resources contests the often heavy weight of scientific discourse in making assumptions about the significance of local practices (Goldman et al. 2011). In this view, scientific assertions about 
resource degradation are not discounted but rather situated in a political context that recasts the complexity of realities on the ground (Bixler et al. 2015; Forsyth 2003). The material state of natural resources is not the only consideration; rather, how they are discussed and understood is also of crucial importance (Bixler et al. 2015). Within this frame, local discourses about natural resources can be better understood as multiple and contested, allowing for more inclusive consideration of womens' practices and knowledge, and acknowledging that different actors understand conservation and associated rights in varied ways (Jones 2006; Vaccaro et al. 2013).

How have womens' perceptions and experiences surrounding these essential natural resources changed over time, and what do these changes tell us about local resource use practices? In particular, how do women as the primary resource users access the materials they need, and how have these patterns shifted? What can women's ability or failure to access necessary resource tell us about environmental practices and the social networks in which they are enacted? To respond to these questions, the research engaged with women who make crafts from six village areas in Ngamiland, the northwestern-most region of Botswana where the majority of craftmakers reside. These women participate in nine differently organized producer groups, as well as private shops, a craft shop operated by the Botswana Council of Churches in Etsha 6, and BotswanaCraft (a wholesale buyer based in the capital city of Gaborone). This range of groups reflects multiple ways of accessing the market as well as complex relationships with localized natural resources. What is evident across groups, however, is that women are increasingly cognizant of the need to manage resources sustainably, while making strategic use of the mechanisms available to them to access broader markets.

Because the primary questions of this study reflect concern for local resource use in the context of using tourism to change conservation incentives, the discussion is framed in terms of community-based conservation, or in Botswana's case, community-based natural resource management (CBNRM). Some of the producer groups who participated in this study are either organized as trusts and/or are connected to other community-based projects, such as the new Peo Crafts trading post established by the CBNRM trust at Tsodilo Hills. Others are supported by facilitating NGOs involved in CBNRM, such as the Itoseng Bomme weaving group in Shakawe's connection to TOCADI, an NGO working along the panhandle of the Okavango River. Many of these groups have also benefitted from environmental education programs to raise awareness about sustainable use conducted by NGOs in support of CBNRM. But even though most of these groups do not operate formalized, institutional CBNRM, they offer the opportunity to consider a more expansive notion of community involvement in conservation than is proffered by the wildlife-centric discourse about CBNRM in Botswana and southern Africa more generally.

The article first discusses women's access to natural resources in the context of current assessments of CBNRM in the region, which brings attention to the gendered focus on wildlife that is characteristic of much of what is considered to be community-based conservation. Next, it briefly describes the methodological approach of the study, followed by an overview of the importance of craft in the context of changing patterns of tourism in Botswana. It then engages the notion of scarcity - firstly in previous studies and secondly in the current project. Finally, it raises several additional issues regarding the use of resources, and offers some concluding thoughts on the importance of including women's perspectives of community-based conservation and thinking beyond wildlife.

\section{Craft in the context of Community-Based Conservation}

The turn away from fortress conservation (Brockington 2002; Neumann 1998) towards communitybased conservation was arguably reflective of an effort to make conservation more, not less, inclusive (Blaikie 2006; Murphree 2009; Swatuk 2005; Taylor 2009). Community-based conservation, or communitybased natural resource management (CBNRM) proliferated as a strategy from the late 1980s, especially in southern Africa as Zimbabwe's CAMPFIRE program and Namibia's communal conservancies provided key regional examples for the implementation of decentralized management with a participatory intent. The primary motivation of these initiatives was to shift economic incentives away from hunting (or 'poaching') and towards conservation of wildlife by providing rural communities with access to income from tourism 
predicated on the presence of wildlife. In some areas, this included management of forest resources - but in most, the emphasis on wildlife was primary.

CBNRM has been criticized on multiple fronts, including failure or mixed results in addressing poverty and inequality (Blaikie 2006; Brockington, Igoe and Soltau 2006; Li 2002), a lack of interest or meaningful participation on the part of those village areas "included" in projects (Bixler et al. 2015; Musumali et al. 2007; Songorwa 1999; Thakadu 2005; Twyman 2000), creating conflict (Meer and Schnurr 2004), weak accountability for funds (Collomb et al. 2010), and consisting primarily of an effort to extend the surveillance of the state (Schafer and Bell 2002). There is also concern over the importation of a Westernstyle management approach into rural communities that lack the capacity to meet externally imposed expectations about project structure and democratic norms, like transparency. Moreover, some suggest that a competing trend towards scaling up to regional or landscape level approaches to conservation may create costs for indigenous communities (Metcalfe and Kepe 2008; Mulrennan et al. 2012) rather than enhance local participation, or that "the few successes [of CBNRM] have been undermined by neoliberalism-induced socioeconomic differentiation" (Dressler et al. 2010).

Others argue that CBNRM clearly has the potential - realized in some projects - to improve conservation outcomes and bring financial benefits to local communities (Child and Barnes 2010; Jones and Weaver 2009; Naidoo et al. 2011; Taylor 2009) and to shift local attitudes about conservation from negative to positive (Mbaiwa and Stronza 2011). This potential is most likely to be realized when projects get the incentives right (Suich 2013). CBNRM may also have a larger-than-local significance, such as connecting local communities to the global economy and enabling continuous social mobilization for change in rural areas (Rodary 2009) or possessing the possibility of supporting development of locally-based natural, human, social, and financial capital (Dressler and Büscher 2008). Even more broadly, globalized efforts to prioritize biodiversity conservation often remain "in serious tension with other knowledge frames and experiences regarding 'the environment"' (Sullivan 2006: 108), creating or reinforcing power differences in whose expertise is understood to have value.

Southern Africa remains the locus of many CBNRM initiatives, and holds a certain importance in broader discussions of CBNRM because of the early adoption of the strategy in the region (Dressler et al. 2010). At the same time, most of the argument about CBNRM in Southern Africa has been directed to wildlife conservation. The economic balancing act of providing communities with financial incentives to stop hunting wildlife led to a myopia that, especially in the beginning, almost entirely excluded women from these projects. Decisions about sustainable use, trophy hunting, and guiding tourists to view charismatic species were the cultural domain of men. This gendered responsibility and interest "is viewed as a continuation of the traditional division of labor. The fact that women are also users and managers of natural resources is usually ignored; thus, women are left with few direct benefits and some negative impacts" (Hunter, Hitchcock and Wyckoff-Baird 1990: 448).

Despite women's knowledge of forest resources, understanding their participation in community projects and the institutions governing them also remains "a little addressed question" (Agarwal 2009: 2785). This means that much of women's work and expertise remains invisible or excluded, even in the context of projects aimed at enhancing the same resources about which women have significant knowledge. This is where a political ecology lens becomes especially important; expanding notions of power and authority can open up spaces in which women's labor and perspectives become not only more visible, but are vested with more significance. In particular, recent work in this vein demonstrates that even while women continue to struggle for equal access to resources and decision-making, even relatively small opportunities to participate more actively in development processes can yield empowerment (Goldman and Little 2015). While many CBNRM projects have had mixed results for women (Khumalo and Freimund 2014), this does not mean that CBNRM is the only filter through which to understand women's use of and access to natural resources - even in areas where CBNRM has proliferated.

A broader and more inclusive notion of resource use and participation in conservation, then, is helpful in elucidating a clearer, gendered understanding of environmental practices. Even in the context of conservation projects that have come to recognize the importance of traditional ecological knowledge (TEK), "women and their roles in the conservation debate remains rather superficial, and is often reduced to being figurative" (Vencatesan 2008: 1120). Exclusion yields significant constraints, such as male dominance in 
decision-making and inequitable benefit sharing (Mukadasi and Nabalegwa 2007) or a lack of access to resources themselves (Boyer-Rechlin 2010; Molnar 1997) and ongoing contestation over land (Goldman and Little 2015). Recognizing that conservation comes at a cost, however, the sustainable extraction of natural resources remains a way to ensure community-level benefits from living with protected areas (Mwakaje et al. 2012).

Even in a literature rich with multidirectional critiques, then, most of what has been written about CBNRM focuses on formalized projects created by international donors in the context of national level policies and legal frameworks without broader recognition that conservation takes place at the community level in many forms (Torquebiau and Taylor 2009). In Southern Africa, for example, many informal networks of women craftmakers have emerged through the efforts of women themselves at the village level to develop informal networks through which they might take advantage of growing tourist infrastructure. Craft production, however, usually relies on natural resources, and how those resources are used and managed has changed over time. In particular, the harvest and use of locally available natural resources to make crafts to sell to tourists began to grow and expand - but so have locally based, user-driven initiatives through which use is monitored and trees are replaced. While often excluded by formal CBNRM initiatives, then, women have often organized themselves to monitor access to resources, teach harvesting and weaving techniques, and using social networks to assist each other with better market access. To shed light on these often overlooked experiences, "Feminist political ecology focuses on the ways in which site-specific ecological and livelihood systems are linked into national and global environmental, economic, and political systems which shape, enable, and limit the opportunities and constraints occurring at the local level" (Thomas-Slayer et al. 1996: 296).

In Botswana, for example, women in Shorobe (on the southern edge of the Okavango Delta) have revived a palm plantation in which they are growing trees, and in the Etsha villages further north the Ngamiland Basket Weaver's Trust, a group of women who weave, solicited and received support from the Department of Forestry to set up and operate a tree nursery (for palm as well as dye products and other trees). In Namibia's Zambezi Region to the north, community resource monitors (formally part of conservancies, Namibia's recognized CBNRM structures) have been working in villages for several decades, collecting information about resource use, teaching sustainable harvesting techniques, and helping women access markets. These kinds of examples - some with the support of formal CBNRM projects, some not - are spaces in which women themselves have not only worked to carve out room for and recognition of their livelihoods, but in which they have struggled against the broader of view of many conservation initiatives whose wildlifecentric approaches marginalize them. In one view, "Experience has shown, however, that unless women are specifically targeted as beneficiaries, economic development projects ostensibly directed to both women and men rarely involve women" (Hunter et al. 1990: 450). At the same time, this certainly does not mean that women are completely incapable of creating their own livelihood strategies that also recognize the importance of conservation.

The argument that CBNRM has failed, then, is in itself overly focused on protecting wildlife as the only conservation goal of community work, and largely ignores the successes and struggles of women who harvest and manage natural resources. These need to be included in conversations about benefitting from conservation, but not only where significant economic benefits have been generated or where wildlife populations have increased. Neither view offers a complete picture with a broader notion of what community-based conservation is and who participates in it - as well as who benefits or does not. Iterative conversations with women about the ways in which they use natural resources, as well as adopting comparative views of how crafts are produced, are instructive in revealing the broader successes and shortcomings of formalized CBNRM.

\section{Methodology}

Eighty-six women who make crafts were interviewed in the Etshas, Gumare, Maun, Seronga, Shakawe, and Shorobe in the first half of 2013. All but six of these women were weavers, as basket making constitutes the most common form of craftmaking in Ngamiland. The majority of women interviewed were between the ages of 30 and 49; only nine women were under 30. More striking is the fact that $40 \%$ of the women interviewed live in female-headed households, and only $18 \%$ of those households have access to 
formal, cash-based employment. These conditions men craft is an important means to access cash, crucial for many women and their families.

A standard set of questions focused on four key areas: the respondent's personal experiences with craftmaking (learning, training, selling and its cultural significance); access to resources and raw materials for making crafts; relationships with local markets as well as formal and informal producer groups; and the economic significance of crafts for individual households. Individual interviews were conducted in the context of village level producer group meetings, facilitated by multiple visits to each group/shop. In this way, each visit began with informal meetings with shop managers and group leaders to ask permission to return to conduct interviews. These first conversations represented an initial opportunity for women to begin to understand the purpose of the study, to make suggestions, raise their own questions, and to allow time to gather other women together. In each case, upon return visits for individual interviews, the numbers of women who participated far exceeded expectations.

In addition to individual interviews, visits were made to local venues for craft sales in each village area for informal discussion with shop employees and/or managers, and an examination of products sold with an eye towards looking for locally made products and considering quality and sales presentation. To further examine the ways in which these village-based shops connect to the broader tourist market, additional shop visits were made in Maun to most of the outlets where crafts and/or souvenirs are sold. To make the importance of craftmaking clear, it is useful to briefly consider the position of tourism in Botswana's economy and the ways in which craft production has changed over time.

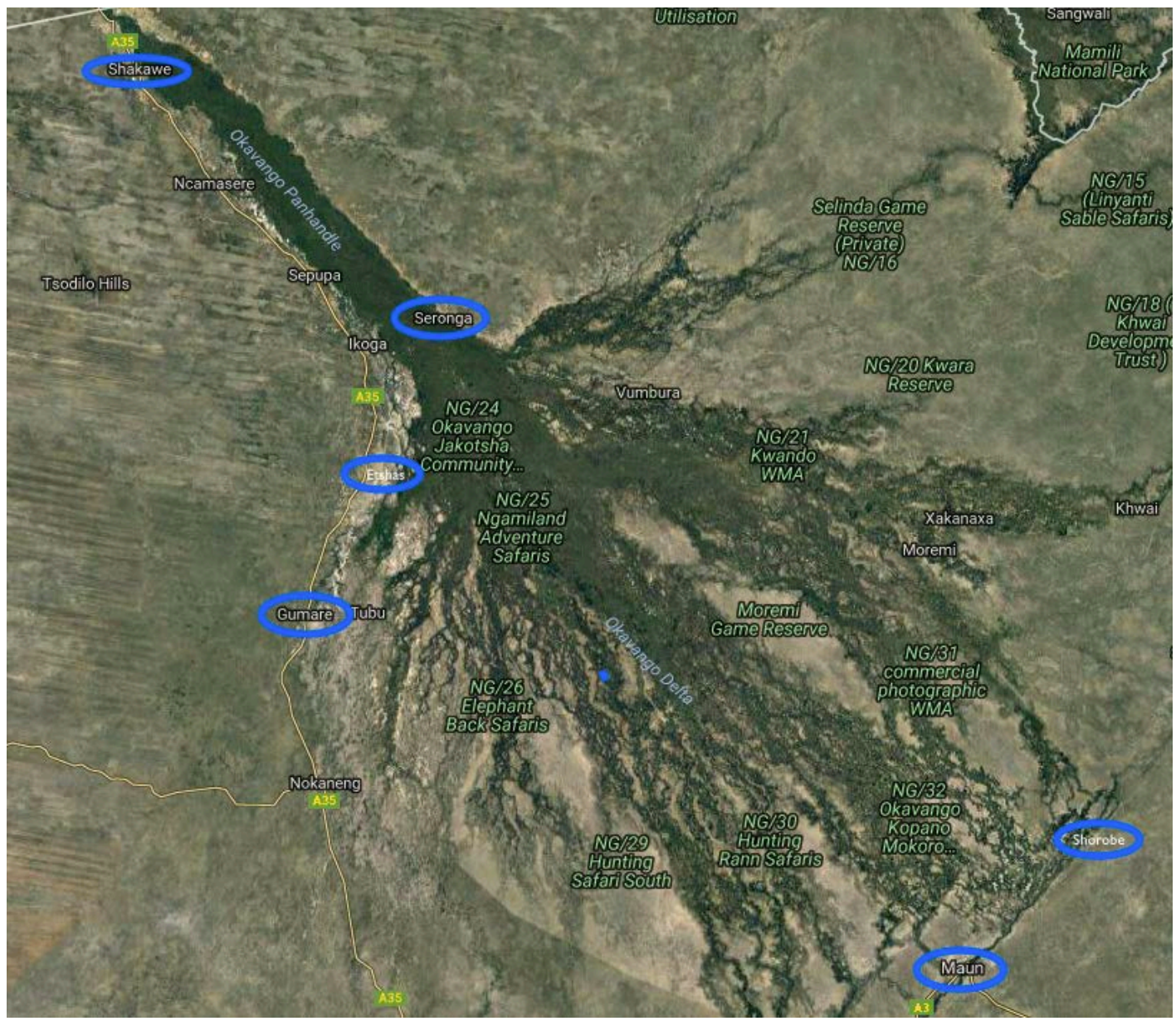

Figure 1: Map of study area with places in the text highlighted. 


\section{Tourism in Botswana: rising and changing}

As diamond sales began to decline in 2009, it is estimated that services now constitute more than half of Botswana's US\$15 billion GDP [agriculture 2\%, industry inclusive of mining $45 \%$, services including tourism 53\%]. The World Travel and Tourism Council (WTTW) placed the total (direct and indirect) contribution of travel and tourism to Botswana's GDP at 6.5\%, and projected an increase to nearly $10 \%$ by 2022. Tourism to Botswana increased steadily through the early to mid-2000s, seeing approximately 850,000 inbound, overnight tourist arrivals in 1999 but 2.5 million in 2010 (UNWTO 2011). The largest increases, however, were pre-2008 - for example, with jumps from 1.64 million in 2006 to 1.97 million in 2007, and to 2.34 million in 2009. This leveling in recent years is closely associated with the worldwide economic downturn, although the numbers of tourists visiting Botswana is still expected to increase annually over the next ten years.

Botswana's high-end, low volume tourism policy has also played a role in limiting accessibility for tourists as part of a desire to strengthen environmental protection and not to overtax key sites with too many visitors, like the Okavango Delta and Chobe National Park. Recently, conversation has also turned towards the possible promotion of cultural tourism in addition to safaris, leading to discussion about ways that different cultural traditions may offer experiences to tourists to enrich their time in Botswana, or may themselves attract visits. This possible expansion of offerings to tourists is especially important because while Botswana has reached 'middle income' status [2012 GDP per capita of US\$16,800], an estimated 30\% of its population still lives below the poverty line.

Poverty is particularly widespread in the rural and outlying areas where this study is focused. Women who participated in the research consistently told me how the cash they earned from craft was vital, since it sends their children to school, supplies their households with food and necessities, and pays for health care and other basic needs. When asked why they make crafts, 68 out of 86 women interviewed indicated that it was for income. But remarkably, in the follow-up question that inquired why crafts might be important besides money, a plurality of women (31 out of 86) still insisted that the income was the most important thing, over personal enjoyment, using the products at home, improving their skills, or their cultural significance. Nested within this understanding is a feeling of empowerment that comes with the entrepreneurial experience of producing something for sale, as women seek and create opportunities to earn their living (see Hovorka 2006).

The promotion of a local conservation ethic has also been advanced by Botswana's CBNRM program, and tourism is touted as increasingly important as income from diamond declines. Heritage tourism, however, has only recently entered the national discourse, which has been intensely wildlife-focused with charismatic megafauna as the major draw (DeMotts and Hoon 2012; Giraudo 2011; Keitumetse 2009).

\section{Producers and products}

Terry (1999) estimated a total of 5,000 craft producers in Botswana as of 1992; 4,200 of these were making "traditional crafts" and nearly $80 \%$ of them were women. Craftmakers in Ngamiland outnumbered all other regions of Botswana combined, with $58 \%$ of the total (nearly 3,000), and basket making was the primary focus of nearly half of the country's craftmakers. While the current numbers are not known, it is likely to be at least a little somewhat smaller than these previous estimates, given that fewer women in the younger generations now weave to sell. The primacy of Ngamiland in the craft industry has been attributed to market development initiatives such as Botswanacraft (Terry 2001); additional factors certainly include the availability of resources and cultural traditions regarding the uses of baskets or other crafts. More recently, increasing levels of tourism make producing for sale more appealing to women, as well as providing more potential sales outlets.

The primary craft of Ngamiland is the mokola palm (Hyphaene petersiana) basket, woven from thin strips of palm leaves harvest and boiled with the roots and bark of various trees to color them in rich earthy shades. The locus of basketmaking is in Etsha 1-13, cattle posts turned village areas on the western panhandle of the Okavango River settled by Hambukushu refugees. They moved south from Angola in the late 1960s. Even baskets made in Maun, for example, are often made by women who are originally from the 
Etshas. But baskets are made throughout Ngamiland, with some variation in colors, patterns, and stitching techniques depending on tradition, and on available resources and materials (Figure 2). The previous studies of weaving (Mbaiwa 2004; Terry 1986, 1999, 2001) have demonstrated its importance in cultural and livelihood terms, placing it among multiple livelihood strategies used to meet basic needs.

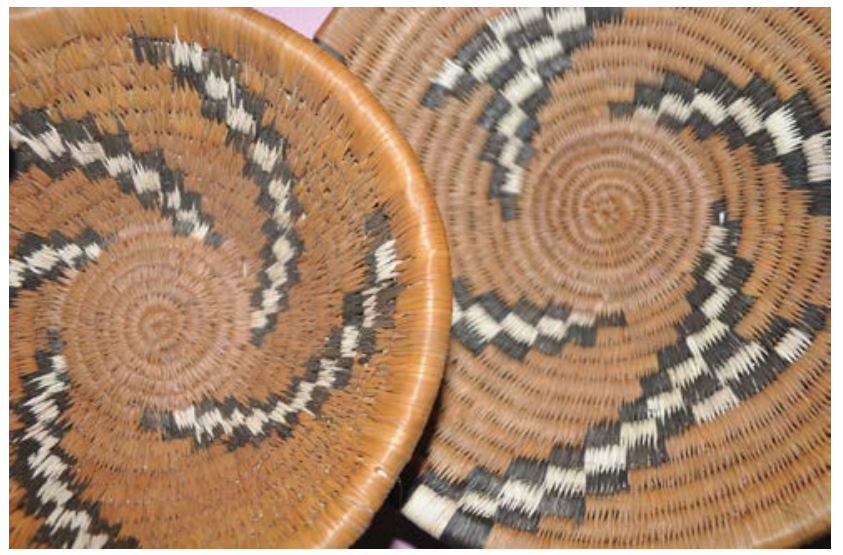

Pattern called the Ribs of the Giraffe, with a lower quality stitching on the left and higher quality on the right. Photo taken by author at Ngwao Boswa in Gumare.
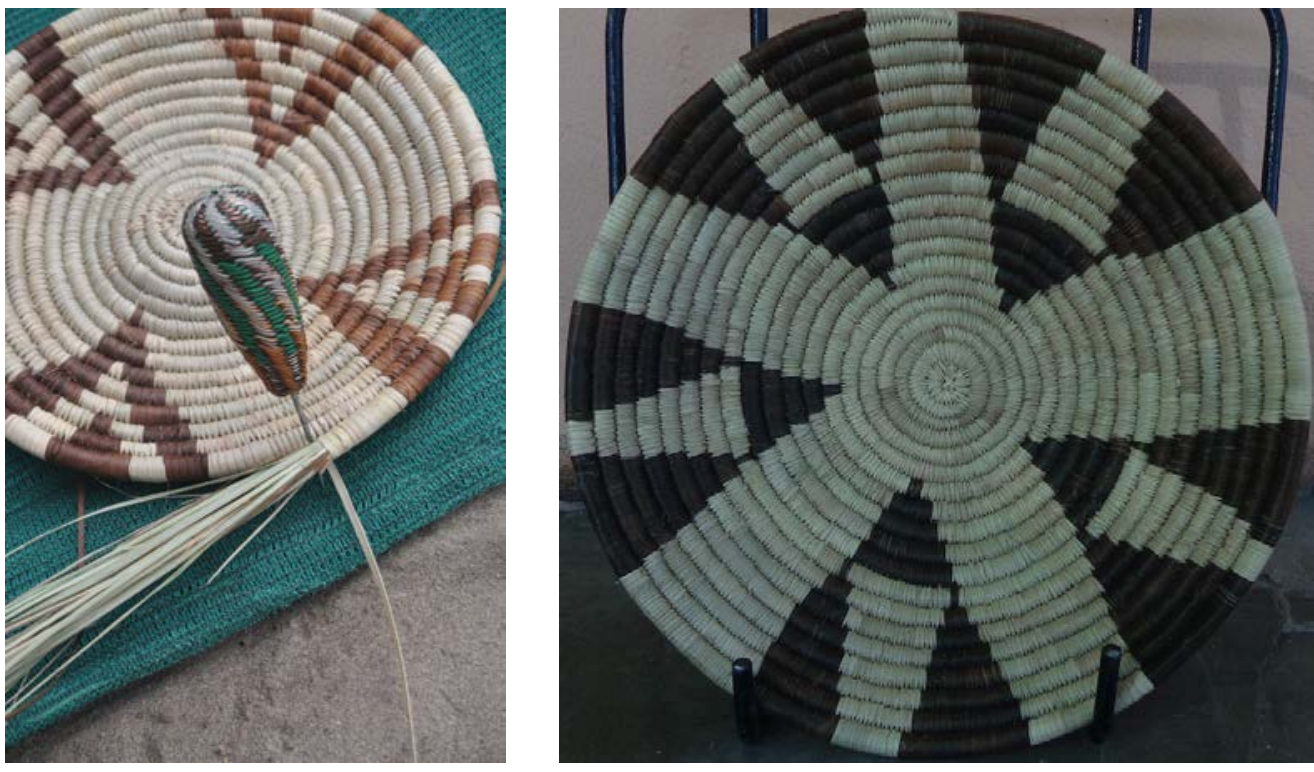

Incomplete basket, pattern Flight of the Swallow. On the left, showing the wrapping technique and the needle used to make holes for threading the palm. On the right, a completed basket with a variation on the same pattern. Photo on the left taken by author in Maun; photo on the right taken by Jason Rison, research assistant, also in Maun.

Figure 2: Typical Botswana baskets. 
Women generally learn to weave from their mothers and grandmothers; sales to tourists did not begin until the 1960s and 1970s, but baskets were used at home for storage and other purposes. In addition to traditional pride of place of baskets, they remain of major importance for local livelihoods, and not only for women without cash-based employment. Many women continue to make and sell baskets as a way to help support themselves and their families. Many villages have either formally or informally organized producer groups consisting of women who make baskets; these groups provide sales outlets, training, and many other forms of support for craftmakers.

\section{Previous studies and concerns about scarcity}

Pressure on palm and dye resources has been a concern since the commercialization of the basket industry in Ngamiland in the mid 1970s. Concerns about depletion of resources have been articulated in studies and by NGOs throughout the last 40 years - beginning just after Botswanacraft's move to commercialize the industry in 1975. The ability to sell baskets for cash can lead to shortages of materials and strain existing natural resources, and has the potential to create problems over access to resources if they are harvested improperly, or by people living outside a given area. At the same time, there is a great deal of evidence that regulations and harvesting behaviors have changed over time in ways that reflect concern for careful use of natural materials.

Most previous studies of the status of natural resources used in basket weaving focused on the area of the panhandle from Gumare to Shakawe (usually a smaller area within that, and often with special attention to the Etshas). In the 1980s Cunningham and Milton conducted and wrote several assessments of the natural resources used in basket weaving that expressed major concerns over the utilization of mokola and dye plants (1982, 1987). The study predicted that without limitations and regulation by both local officials and producer groups, the industry would collapse. Seventy-three percent of craftmakers interviewed in the 1982 study indicated that they had a problem of some kind accessing palm and $80 \%$ indicated that there were problems obtaining dye (Cunningham and Milton 1982). These difficulties included the growing distance involved to harvest, digging, thorns on the palm leaves, the labor of preparation and boiling, and other factors.

Such difficulties illustrate that even when resources are available, making baskets is hard work. But difficulties should not necessarily be assumed to reflect resource depletion and must be carefully unpacked. For example, also in the 1982 study, 19\% of basket weavers indicated that they did not have a problem accessing mokola. Given the problems described in the act of harvesting itself, "free of difficulty" could have meant that there were still usable trees within the immediate area of residence. But Cunningham (1988) indicated that "Interviews and discussions with basket weavers in 1982 and 1983 confirmed that both dye and palm leaves were more difficult to obtain [than in the past]" (Cunningham 1988: 13), and that this was especially true in the Etshas. Similarly, in interviews in 1984 and 1986 (Terry 1984, 1986; data cited in Cunningham 1988) craftmakers were far more likely to indicate shortages of basket materials than no shortages. Overharvesting remained a concern in further studies in the early 2000s, and the assertion that too many people were harvesting was made more frequently (Kgathi, Mmopelwa, and Mosepele 2005; Mbaiwa 2004).

This history of difficulties and concerns is important for understanding the labor involved in making baskets, and the ways in which harvesting may impact the natural environment over time. The consistent perception of difficulty on the part of craftmakers shows that even under favorable circumstances, collecting and preparing materials for weaving is a tremendous investment of time and energy. Women may, at times, walk for up to ten kilometers; the harvesting work itself is tricky as palm leaves are sharp and can cause injury. Digging for roots for dye is laborious - not to mention carrying everything home.

The results of this study, however, show that women speak differently about the current state of resources in their village areas than they have in the past. As previously mentioned, it is likely that the number of women making crafts has declined; but at the same time, perceptions are important due to the consistent predictions of looming shortages made in earlier research studies (as recent as the early 2000s in Mbaiwa 2004, for example). Almost all of them indicated that women perceived there to be fewer raw materials available at the time of the study than in the past. This is not consistently the case in the current 
study, in which half of all women interviewed (43 out of 86) indicated no problem accessing resources rather different to the first survey in 1982. A more detailed discussion of these findings follows.

\section{Location and resource access over time}

Most of the women I interviewed indicated that they are able to access the materials they need in their immediate village areas (within walking distance). Even when some are unavailable locally, there are other ways of acquiring them; not a single craftmaker indicated that she was unable to get the raw materials she needed. This does not, of course, guarantee that all harvesting and collecting is done in a sustainable manner, nor does it necessarily mean that there is no resource shortage. It does indicate that women have developed systems and relationships that allow them to acquire needed materials. In this way, accessing resources parallels womens' networks that help them access markets. In Seronga, they may purchase palm from Jao; in the Etshas, they may pool their funds to send someone to Maun with their baskets to sell, while women in Maun may travel to their home villages further north to collect materials. These informal social networks engender access to both resources and markets and show women's ingenuity in overcoming difficulties.

At the same time, it remains important to understand where resources and being accessed and by whom. Table 1 is organized by village area, and shows a wide range of responses to a question about where craft materials come from:

\begin{tabular}{|c|c|c|c|c|c|c|}
\hline & ETSHAS & GUMARE & MAUN & SERONGA & SHAKAWE & SHOROBE \\
\hline $\begin{array}{c}\text { Collect/harvest } \\
\text { locally (walk) }\end{array}$ & 20 & 7 & 5 & 6 & 13 & 7 \\
\hline $\begin{array}{c}\text { Travel to } \\
\text { collect/harvest }\end{array}$ & 2 & 5 & 5 & 3 & 3 & 0 \\
\hline Buy always & 0 & 0 & 3 & 14 & 0 & 0 \\
\hline $\begin{array}{c}\text { Buy sometimes } \\
\text { Difficulty getting } \\
\text { materials }\end{array}$ & 4 & 1 & 4 & 0 & 0 & 3 \\
\hline
\end{tabular}

Table 1: Where do you get the materials to make [your crafts]?

Table 1 shows that most women are still able to harvest their own materials for craftmaking, even if it may involve a long walk. Buying remains rare, although it is used strategically in some places (it is high in Seronga because of the previously mentioned six women who sew felt and stitch seed beads, which must be purchased and brought from Maun, and the fact that there is no palm that grows locally). For example, it is common for women in Seronga to buy palm from Jao or, at times, to go there to harvest it themselves, but dye plants are plentiful around Seronga. In Shorobe, dye is often more difficult to access than palm, which is everywhere in the village and in a recently revived plantation nearby. Women in the Etshas and Shorobe mentioned getting makokothi (dye tree) from Shakawe, while women in Shakawe harvest palm primarily in Mohembo (and sometimes in Nxamasere, which also comes with the risk of elephants eating the palm). In all villages, women use different strategies at different times to access needed resources. They may buy if they do not have time to collect, and they may trade dye for palm or palm for dye.

There is a history of village-level regulations for harvesting dating back to the 1950s and 1960s near Etsha, but this is not the case in all areas. On the whole, very few women mentioned any significant problems with existing enforcement of regulations. The most significant change occurred when people were no longer 
allowed to use hoes or axes to harvest, which had a positive effect on trees by causing less damage (Bishop and Scoones 1994). The only place in which purchasing permits was discussed was in Shakawe. Women generally go to Mohembo to harvest and often in groups, meaning that permits are at times purchased jointly by a group of women rather than by individuals. In other areas, some women mentioned that they were afraid of more regulations being imposed (from Forestry), but nowhere did women indicate that regulations or permit systems were consistently enforced, or preventing them from harvesting.

At the same time, it is crucial to understand the kinds of difficulties women encounter in harvesting. Difficulties in getting materials were mentioned. But other changes must be considered as well; for example, several women in the Etshas stated that they struggle to collect palm because they have now moved closer to the road and have to walk further than in the past. It is most important is to understand the complex responses to change in resource access over time (Table 2).

\begin{tabular}{|c|c|c|c|c|c|c|}
\hline & ETSHAS & GUMARE & MAUN & SERONGA & SHAKAWE & SHOROBE \\
\hline $\begin{array}{c}\text { Yes, less resource } \\
\text { available }\end{array}$ & 9 & 7 & 5 & 0 & 1 & 0 \\
\hline $\begin{array}{c}\text { Trees are too far } \\
\text { away }\end{array}$ & 6 & 2 & 0 & 0 & 0 & 2 \\
\hline $\begin{array}{c}\text { Too many people } \\
\text { collecting }\end{array}$ & 5 & 1 & 5 & 3 & 5 & 0 \\
\hline $\begin{array}{c}\text { Same as before } \\
\text { [=not more } \\
\text { difficult }\end{array}$ & 4 & 2 & 1 & 4 & 14 & 4 \\
\hline $\begin{array}{c}\text { There is plenty/so } \\
\text { no problem }\end{array}$ & 9 & 7 & 5 & 0 & 3 & 5 \\
\hline $\begin{array}{c}\text { Elephants are a } \\
\text { problem }\end{array}$ & 3 & 6 & 0 & 0 & 0 & 0 \\
\hline $\begin{array}{c}\text { Laws or permit } \\
\text { regulations }\end{array}$ & 3 & 0 & 0 & 0 & 5 \\
\hline
\end{tabular}

Table 2: Responses to the question, is it more difficult to get these resources than it used to be? If yes, why?

Table 2 shows a variety of responses to a complex question. In every village, women talked about the importance of sustainable harvesting practices and their own efforts to teach others to cut carefully, and not to kill palm or dye trees. But at the same time, many women gave multi-layered responses; since the question is essentially open-ended. For example, a woman might assert that she could get palm, but it was too far to walk and there was not as much as there used to be. This would lead to her response being counted twice in Table 2. In other instances, palm for weaving is said to be on sale, but dye plants are easily collected, leading to what might appear to be conflicting indicators in one place.

These differences also varied by area. In the Etshas, the primary difficulty is access to dye plants. Some women assert that there are fewer palm trees than there used to be; attributed in part to more people harvesting, but also to elephants killing them. Resource accessibility can also vary by season; at times, it may be necessary to go by mokoro (canoe) to harvest palm, for example, raising the amount of time and difficulty. Two of the women who indicated that the resources are too far away, did so not because the trees are fewer, 
but because their households have recently moved closer to the road. In these ways, it is crucial to unpack causes of described difficulties and not assume that overharvesting is widespread.

In Gumare, there is a similar balance to the Etshas in the perception that fewer resources are available, and yet they remain plentiful. A number of the women who weave for Ngwao Boswa harvest at their cattleposts further out on the floodplain, in the direction of Tubu. Elephants are a problem here too, especially for women who would otherwise be willing to walk long distances towards the river to collect.

In Maun, the strategies for accessing resources vary the most. This is not surprising, given that women living in the peri-urban areas of Boseja and Shashe on the edges of Maun are not likely to have local access to palm and dye plants. Many of the weavers in Maun are originally from the Etshas, and some of them indicated that they travel home to collect. Others - particularly those with formal employment or other sources of cash - periodically or regularly buy palm that is already prepared.

In Seronga, dye is everywhere but palm is nonexistent, and this gap is not new, nor is it caused by overharvesting. Women have consequently worked out ways of getting palm from Jao. Those who have learned sewing and beadwork as part of the Tipatizane group purchase their supplies from the group facilitator, who brings seed beads, felt, thread, and other supplies from Maun.

Shakawe respondents reported the least difficulty accessing resources. Palm remains plentiful at Mohembo, although elephants are also becoming a problem. Some of the women in Itoseng Bomme also travel to their home villages (Gudigwa, Nxamasere) to collect, which is true of some women in other groups as well.

In Shorobe, palm is everywhere - even in the courtyard outside the Shorobe Baskets shop. A number of local weavers mentioned the importance of a plantation on the western edge of the village, demonstrating pride in ownership as much as benefits from supply. Dye is more difficult to locate, however, mostly due to elephant behavior. Several women indicated that they walk to the river at certain times of day only, to avoid them.

These comments - and counting a single woman's response more than once rather than forcing her answer into a single category - bring into sharp relief the idea that it can be difficult to access resources, but not necessarily getting any worse. The most commonly given response across village areas was that there are plenty of resources, and that accessing them is not a problem, and in none of the six village areas was the response of "less resource available" more common than "there is plenty." These two responses were given an equal number of times in three villages, while "there is plenty" was more frequent in the remaining three. Even in the three village areas where women said that there is less resource availability more often than they said it is the same, they still indicated that "there is plenty" equally as often as indicating resources have diminished. Interestingly, there is another important consideration in two of the three villages where women did more frequently assert that scarcity has increased. In both the Etshas and Gumare, elephants were a commonly discussed problem. Elephants were also discussed in Shorobe, but palm is plentiful and close by in Shorobe - making encountering elephants less of a problem. Women in Maun also indicated that it is not as easy to get resources as it used to be. Given that Maun - though still spoken of as a village - is an urbanizing area far larger than any of the others in this study, it is not surprising that accessing natural resources in the immediate area is more difficult.

Further, indicating that harvest is more difficult does not mean that it is always safe to assume this is because of overutilization. One woman in Etsha 9 described the situation as follows: "It is more difficult, there are more laws and government wants us to have permits but we sneak in and out. It is also far sometimes to cross water to get to palm trees." Here, difficulty is significant - but in her experience, not caused by women using too much palm. Another woman living nearby indicated that her increased difficulty was because of the sustainable harvesting rules - the lack of ability to use an ax, as previously mentioned. This shift towards more sustainable harvesting practices is also supported by contrasting the two quotations at the beginning of this article. In environmental terms, difficulty here is actually a positive sign, in that while cutting may take longer it suggests that at least some women have adopted sustainable use practices.

This does not mean that it is always easy to get raw materials. Many women said that it is difficult to get what they need, but there has been little change over time. Given also that most women who weave have 
been doing so for many years (most are middle aged or elderly), it is significant that they report no increase in difficulty. It is crucial to note, however, that these assertions about 'more and less difficulty' cannot be assumed to mean that there is no overharvesting or shortage. To determine the actual prevalence of palm and dye trees in each area, transects would have to be conducted over time and compared. Nonetheless, the ways in which women talk about what is available to them have clearly shifted compared to previous surveys, and this is significant for three reasons.

First, there is clear evidence that sustainable harvesting practices have become a regular part of cutting palm. In individual interviews and in informal group discussions, women regularly brought up the importance of harvesting with limits - either by cutting technique, amount taken, or seasonality. While formal regulation was rarely mentioned -in one case, a woman did indicate that they sometimes circumvent it - there was far more discussion of informal changes in harvesting practices to ensure that resources continue to be available.

Second, the relationships between and among these groups of weavers help them manage problems of access to both resources and markets. Trading and selling palm or dye plants is possible because of the connections between and among these weaving groups. Some groups have also benefitted from connections to NGOs and formal CBNRM projects, but this is not the case across the board. However, these networks of weavers suggest that information flows are facilitated by informal connections as well as formal ones. Here, then, CBNRM projects may have had positive educational effects on harvesting practices that are not accounted for in broader discussion of CBNRM.

And third, the single biggest problem that women consistently raised was the need to sell more of their work, not the problem of locating enough palm or dye plants to be able to weave. "We are crying for markets" was a common refrain, with women consistently expressing concerns about how long it takes to sell their baskets. In some cases, of course, this may be more a question of poor quality than a lack of market because consistent observation throughout the study area showed that good quality baskets sold quickly, no matter where they were made. But at the same time, the challenges in accessing the broader tourist market remain significant, even as womens' informal social networks perform the function of creating strategies for getting baskets to sales points - for example, as women may give their baskets to someone going to Maun from the Etshas, record what is being taken, and rely on trust that they will be delivered and payments will be returned.

\section{Further environmental considerations}

An important growing tension - which has also been previously noted (Mbaiwa 2004) - is that a larger focus on wildlife conservation has had a negative impact on women who use forest resources. In particular, the growing elephant population creates two problems. One, elephants eat and destroy palm trees, sometime close to where women harvest palm leaves and/or dye trees. This means that women have to go further afield to harvest.

Second, the mere presence of elephants means that women may be afraid of walking into the forest to harvest. The risk of encountering elephants while out harvesting can be too great. But at the same time, women have developed ways of dealing with this problem. One woman in Shorobe indicated that as more elephants were present in their area, they had watched when the elephants move back and forth to the river and made it a habit to go and harvest when they were most likely to be elsewhere. Another added, "[Resources are] plenty and easily accessible but we go when elephants are not around, pressure is building on resources as elephants and cows are eating palm trees more and more these days." In the case of elephants, then, one conservation success leads to other resource difficulties. If CBNRM has contributed to an increase in wildlife, then, it has also made it harder for women to access forest resources.

On the positive side, there is a clear awareness of the need for environmental stewardship. In several meetings with producer groups, women spoke in detail about the need to observe practices that would conserve the resources they use. For example, in Seronga, the women interviewed had an extensive, unprompted discussion about the importance of not cutting reeds too early in the season, because this would mean they would not have had time to dry out and drop their seeds - reducing next year's harvest. This kind 
of awareness shows that women do connect careful use with future availability. It also reinforces the gap between the two comments with which this article began - in which the 1982 study participant commented on poor harvesting practices, while the respondent in 2013 noted sustainable practices.

Women may also substitute what they use - for example, making the core coil from grass instead of entirely of palm - if a resource is strained or not readily available. This can be a problem, but it can also encourage innovation and different styles of baskets - for example, baskets with larger stitches spaced out more widely so as to use less palm. There is also evidence of increased environmental stewardship in many areas, such as the recent revival of the palm plantation at Shorobe and the recent establishment of a palm and dye tree nursery at Etsha 6, the latter with a grant from the Department of Forestry.

One final consideration is that basket work is considered a seasonal enterprise. Women's livelihood strategies shift with the time of year; planting and farming occupy most of December/January until April while harvesting grass and reeds is done in July, August, and September. This means that crafts are most likely to be produced at other times, which can be at odds with tourist demands for crafts as souvenirs in the winter. Additionally, if drought is a factor - as it was in 2013, the study year - this may increase women's need to produce crafts for sale. Many interviewees indicated that the importance of craft income is far greater when crops fail, which may also increase resource pressure. Under drought conditions it is also more likely that both wildlife and livestock may turn to eating palm, which could damage more trees and further complicate supply. This possibility has been documented in north-central Namibia, where livestock browse young palms and represent a threat to the long-term extent and distribution of mature palm trees (Konstant et al. 1995). Seasonality and environmental conditions are crucial considerations in assessing the use of raw materials for crafts. This means, simply put, that what people will say from year to year about resources in their areas will vary, and in this case, it is notable that so many women noted plentitude even in a drought year.

\section{Concluding thoughts}

Meeting with a conservationist overseeing a major development project in Botswana, they indicated that it was a foregone conclusion that resources were in peril and that degradation was widespread. This was in the course of discussing how resource use patterns might have changed over time. They asserted that every time their project - which is known to have money available to spend on community level initiatives - held a village meeting, project representatives were told by village leadership that the trees in their areas were fewer and fewer, subjected to overuse and becoming scarce.

According to the women interviewed, this is not necessarily true - or at least, it is not the whole story. But the discursive juxtaposition of the two narratives is instructive. On one hand, there is a discussion among male conservationists and village-level traditional authorities about existing natural resource problems that may be eligible for project funds, but these are generally held without the women who do the collecting. On the other is an iterative series of group and individual conversations among women who harvest and use those resources, clearly reflecting "the gender division of power to preserve, protect, change, construct, rehabilitate, and restore environments and to regulate the actions of others" (Rocheleau et al. 1996: 10). That these two contexts should lead to different conclusions is not necessarily surprising, but it is reflective of the need to "recognize local, gendered knowledge not only for its intrinsic worth, but also for its valuable contributions to sustainable environments and economies" (Thomas-Slayter et al. 1996: 292).

The interviewees spoke at length about their successes and difficulties, but clearly demonstrated that the presence of problems cannot be assumed to mean widespread overharvesting. They were also positive far more frequently than in previous studies - indicating that sustainable use practices are in place. As shown in other studies with a feminist political ecology lens, "This knowledge is based on their [women's] experience, responsibilities, and daily practice, rather than an intrinsic or essential 'feminine' quality" (Thomas-Slayter et al. 1996: 292). While a complementary scientific assessment of the status of palm and dye trees in these areas would clearly be useful, womens' perspectives demonstrate that existing problems cannot be assumed to be entirely the result of human overutilization, and they reveal far more complex 
factors at play. This difference reminds us that "The very notions of property and resources, so often assumed to be fixed, are both variable between groups and places and dynamic in time" (Rocheleau et al. 1996: 11).

The exclusion of women and their perspectives from management decisions omits crucial sources of knowledge and experience. But women are committing to conserve resources on their own, in this case through their craftmaker groups and informal networks of weavers who share materials and information. CBNRM projects would be well-served by considering a fuller range of what is considered to be communitybased conservation, revealing a complex landscape constituted by "different components of local ecologies" (Leach et al. 1999: 226). It is possible that that the gendered, wildlife-centric lens may be so myopic that it has excluded consideration of positive local trends, in which its educational efforts may have even been a part. The effectiveness of community-based conservation, then, should not be judged only on formalized CBNRM projects, but on an inclusive consideration of the ways in which communities use and conserve all of the natural resources available to them.

\section{References}

Agarwal, B. 2009. Gender and forest conservation: the impacts of women's participation in community forest governance. Ecological Economics 68: 2785-2799.

Bishop, J. and I. Scoones. (eds.) 1994. Beer and baskets: the economics of women's livelihoods in Ngamiland, Botswana. Sustainable Agriculture Programme Research Series 3(1). London: International Institute for Environment and Development.

Bixler, R.P., J. Dell'Angelo, O. Mfune and H. Roba. 2015. The political ecology of participatory conservation: institutions and discourse. Journal of Political Ecology 22: 164-182.

Blaikie, P.M. 2006. Is small really beautiful? Community-based natural resource management in Malawi and Botswana. World Development 34(11): 1942-1957. Researchgate

Boyer-Rechlin, B. 2010. Women in forestry: a study of Kenya's Green Belt Movement and Nepal's Community Forestry Program. Scandinavian Journal of Forest Research 25(S9): 69-72.

Brockington, D. 2002. Fortress conservation: the preservation of the Mkomazi Game Reserve, Tanzania. Oxford: James Currey.

Brockington, D., J. Igoe and K.A. Schmidt-Soltau. 2006. Conservation, human rights, and poverty reduction. Conservation Biology 20(1): 250-252.

Child, B. and G. Barnes. 2010. The conceptual evolution and practice of community-based natural resource management in southern Africa: past, present and future. Environmental Conservation 37(03): 283295.

Collomb, J.G.E., P. Mupeta, G. Barnes and B. Child. 2010. Integrating governance and socioeconomic indicators to assess the performance of community-based natural resources management in Caprivi (Namibia). Environmental Conservation 37(3): 303-309.

Cunningham, A.B. 1988. Botswana basketry resources: resource management of plants supporting the Ngamiland basketry industry, 1982-1988. Gaborone: Botswana Craft Marketing Company (Pty) Ltd.

Cunningham, A.B. and S.J. Milton. 1982. A survey of plant resource utilization by the Botswana basket industry in the CFDA, Ngamiland. Unpublished report (available at the Okavango Research Institute library, University of Botswana, Maun).

Cunningham, A.B. and M.E. Terry. 2006. African basketry: grassroots art from Southern Africa. Cape Town: Fernwood Press.

DeMotts, R. and P. Hoon. 2012. Whose elephants? Conserving, compensating, and competing in Northern Botswana. Society and Natural Resources 25(9): 837-851.

Dressler, W. and B. Büscher. 2008. Market triumphalism and the CBNRM 'crises' at the South African section of the Great Limpopo Transfrontier Park. Geoforum 39(1): 452-465. 
Dressler, W., Büscher, B., M. Schoon, D. Brockington, T. Hayes, C.A. Kull and K. Shrestha. 2010. From hope to crisis and back again? A critical history of the global CBNRM narrative. Environmental Conservation 37(1): 5-15.

Forsyth, T.J. 2003. Critical political ecology: the politics of environmental science. London: Routledge.

Goldman, M.J. and M.D Turner. 2011. Introduction. In Goldman, M.J., P. Nadasdy and M.D. Turner (eds.) Knowing nature: conversations at the intersection of political ecology and science studies. Chicago: University of Chicago Press. Pp. 1-23.

Goldman, M.J. and J.S. Little. 2015, Innovative grassroots NGOs and the complex processes of women's empowerment: An empirical investigation from northern Tanzania. World Development 66: 762-777.

Giraudo, R.F. 2011. Intangible heritage and tourism development at the Tsodilo World Heritage Site. Ph.D. dissertation, Anthropology. Berkeley: University of California, Berkeley.

Hovorka, A. 2006. The No. 1 Ladies' Poultry Farm: a feminist political ecology of urban agriculture in Botswana. Gender, Place and Culture 13(3): 207-225.

Hunter, M.L., R.K. Hitchcock and B. Wycoff-Baird. 1990. Women and wildlife in Southern Africa. Conservation Biology 4(4): 448-451.

Jones, S.J. 2006. A political ecology of wildlife conservation in Africa. Review of African Political Economy 109: 483-495.

Jones, B. and L.C. Weaver. 2009. CBNRM in Namibia: growth, trends, lessons and constraints. In Suich, H., B. Child and A. Spencely (eds.) Evolution and innovation in wildlife conservation: parks and game ranches to transfrontier conservation areas. London: Earthscan. Pp. 223-243.

Keitumetse, S.O. 2009. The Eco-tourism of Cultural Heritage Management (ECT-CHM): linking heritage and 'environment' in the Okavango Delta regions of Botswana. International Journal of Heritage Studies 15(2-3): 223-244.

Kgathi, D.L., G. Mmopelwa and K. Mosepele. 2005. Natural resources assessment in the Okavango Delta, Botswana: case studies of some key resources. Natural Resources Forum 29(1) 70-81.

Khumalo, K.E. and W.A. Freimund. 2014. Expanding women's choices through employment? Communitybased natural resource management and women's empowerment in Kwandu conservancy, Namibia. Society and Natural Resources 27(10): 1024-1039.

Konstant, T.L., S. Sullivan and A.B. Cunningham. 1995. The effects of utilization by people and livestock on hyphaene petersiana (arecaceae) basketry resources in the palm savanna of north-central Namibia. Economic Botany 49(4): 345-356. Academia

Leach, M., R. Mearns and I. Scoones. 1999. Environmental entitlements: Dynamics and institutions in community-based natural resource management. World Development 27(2): 225-247.

Li, T.M. 2002. Engaging simplifications: community-based resource management, market processes and state agendas in upland Southeast Asia. World Development 30(2): 265-283.

Mbaiwa, J.E. 2004. Prospects of basket production in promoting sustainable rural livelihoods in the Okavango Delta, Botswana. International Journal of Tourism Research 6(4): 221-235.

Mbaiwa, J.E. and A.L. Stronza. 2011. Changes in resident attitudes towards tourism development and conservation in the Okavango Delta, Botswana. Journal of Environmental Management 92(8): 19501959.

Meer, T. and M.A Schnurr. 2013. The community versus community-based natural resource management: the case of Ndumo game reserve, South Africa. Canadian Journal of Development Studies/Revue canadienne d'études du développement 34(4): 482-497.

Metcalfe, S., and T. Kepe. 2008. "Your Elephant on our land" the struggle to manage wildlife mobility on Zambian Communal Land in the Kavango-Zambezi Transfrontier Conservation Area. The Journal of Environment and Development 17(2): 99-117.

Molnar, A. 1997. Women and international forestry development. In C. Sachs (ed.). Women working in the environment. London: Routledge. Pp.267-276. 
Mukadasi, B., and M. Nabalegwa. 2007. Gender mainstreaming and community participation in plant resource conservation in Buzaya county, Kamuli district, Uganda. African Journal of Ecology 45(s1): 7-12.

Mulrennan, M.E., R. Mark and C.H. Scott. 2012. Revamping community-based conservation through participatory research. The Canadian Geographer/Le Géographe canadien 56(2): 243-259.

Murphree, M.W. 2009. The strategic pillars of communal natural resource management: benefit, empowerment and conservation. Biodiversity and Conservation 18(10): 2551-2562.

Musumali, M.M., T.S. Larsen, and B.P. Kaltenborn 2007. An impasse in community based natural resource management implementation: the case of Zambia and Botswana. Oryx 41(03): 306-313.

Mwakaje, A.G., E. Manyasa, N. Wawire, M. Muchai, D. Ongare, C. Mugoya and A. Nikundiwe. 2013. Community-based conservation, income governance, and poverty alleviation in Tanzania: the case of Serengeti ecosystem. The Journal of Environment and Development 22(1): 51-73.

Naidoo, R., G. Stuart-Hill, L.C. Weaver, J. Tagg, A. Davis and A. Davidson. 2011. Effect of diversity of large wildlife species on financial benefits to local communities in northwest Namibia. Environmental and Resource Economics 48(2): 321-335.

Neumann, R.P. 1998. Imposing wilderness: struggles over livelihood and nature preservation in Africa. Berkeley: University of California Press.

Rocheleau, D., B. Thomas-Slayter and E. Wangari. 1996. Gender and environment: a feminist political ecology perspective. In Rocheleau, D., B. Thomas-Slayter, and E. Wangari (eds.). Feminist political ecology: global issues and local experience. London: Routledge. Pp. 3-26.

Rodary, E. 2009. Mobilizing for nature in southern African community-based conservation policies, or the death of the local. Biodiversity and Conservation 18(10): 2585-2600.

Songorwa, A.N. 1999. Community-based wildlife management (CWM) in Tanzania: are the communities interested? World Development 27(12): 2061-2079.

Suich, H. 2013. The effectiveness of economic incentives for sustaining community based natural resource management. Land Use Policy 31: 441-449.

Sullivan, S. 2006. The elephant in the room? Problematising 'new' (neoliberal) biodiversity conservation. Forum for Development Studies 33(1): 105-135.

Swatuk, L.A. 2005. From "project" to "context": community based natural resource management in Botswana. Global Environmental Politics 5(3): 95-124.

Taylor, R. 2009. Community based natural resource management in Zimbabwe: the experience of CAMPFIRE. Biodiversity and Conservation 18(10): 2563-2583.

Terry, M.E. 1986. The basket industry of Gumare and Tubu. Gaborone: Ministry of Commerce and Industry.

Terry, M.E. 1999. The economic and social significance of the handicraft industry in Botswana. PhD dissertation. London: School of Oriental and African Studies.

Terry, M.E. 2001. An overview of the Botswana handicraft sector. Botswana Notes and Records 33: 129143.

Thakadu, O.T. 2005. Success factors in community based natural resources management in northern Botswana: lessons from practice. Natural Resources Forum 29(3): 199-212.

Thomas-Slayter, B., E. Wangari and D. Rocheleau. 1996. Feminist political ecology: crosscutting themes, theoretical insights, policy implications. In Rocheleau, D., B. Thomas-Slayter, and E. Wangari (eds.). Feminist political ecology: global issues and local experience. London: Routledge. Pp 287-307.

Torquebiau, E. and R.D. Taylor. 2009. Natural resource management by rural citizens in developing countries: innovations still required. Biodiversity and Conservation 18(10): 2537-2550.

Twyman, C. 2000. Participatory conservation? Community-Based Natural Resource Management in Botswana. The Geographical Journal 166(4): 323-335. 
United Nations World Tourism Organization. 2011. Botswana Indicators Participatory conservation? Community-based natural resource management in Botswana, 2006-2010. Downloaded from http://www2.unwto.org

Vaccaro, I., O. Beltran and P.A. Paquet. 2013. Political ecology and conservation policies: some theoretical genealogies. Journal of Political Ecology 20: 255-272.

Vencatesan, J. 2008. Gender and conservation-some issues. Current Science 94(9): 1120-1122.

World Travel and Tourism Council. 2013. Country report, Botswana. Downloaded from http://www.wttc.org/research/economic-impact-research/country-reports/b/botswana/ 